\title{
The Effect of Exchange Rates and Interest Rates of Four Large Economies on the Health of Banks in ASEAN-3
}

\author{
Rudi PURWONO' ${ }^{1}$ Jopie TAMTELAHITU ${ }^{2}$, M. Khoerul MUBIN ${ }^{3}$
}

Received: July 30, 2020 Revised: August 23, 2020 Accepted: September 10, 2020

\begin{abstract}
This study examines how the health of the banks in ASEAN-3 countries namely Indonesia, Malaysia and Thailand respond to the change in exchange rates and foreign interest rates in four large economies. The transmissions of the two external factors through domestic factors in each ASEAN-3 countries eventually affects Non-Performing Loan (NPL) of commercial banks. This study uses the monthly time series data and the renowned Structural Vector Autoregressive (VAR) model comprising five variables, namely exchange rate, foreign interest rate, domestic interest rate, money supply, and non-performing loan (NPL). The results indicate that there are different effects between ASEAN-3 countries, which can be classified as short-run effect and long-run effect. In the long run effect, external factors have a dominant role in determining NPL in ASEAN-3 countries. Yuan has the biggest effect on Malaysia's NPL, while Indonesia is more affected by European interest rates rather than the fluctuation of the US currency and China's interest rates. Among ASEAN-3 countries, Malaysia is the one that is the most vulnerable to external factors. While Thailand's NPL is affected dominantly by domestic factors. This study shows that the Fed Funds Rate (US official interest rate) is not always the dominant factor affecting the health of domestic banks in ASEAN-3.
\end{abstract}

Keywords: Exchange Rates, Interest Rates, Non-Performing Loan, ASEAN, Structural VAR

JEL Classification Code: E42, E43, E51, E52, G21

\section{Introduction}

The flow of funds in the financial system and the economy must be ensured to run smoothly and efficiently (Mishkin, 2015). Banks play an important role in a country's economy. Banks have the main task of channeling funds in the form of loans to the public to make investments. If banks in a country are unstable, they can affect the distribution of income and ultimately increase inequality (Agnello \& Sousa, 2012). Bank stability can be assessed from the level of bank health,

${ }^{1}$ First Author and Corresponding Author. Associate Professor, Department of Economics, Faculty of Economics and Business, Universitas Airlangga, Indonesia [Postal Address: Jalan Airlangga Nomor 4, Gubeng, Surabaya, 60286, Indonesia]

Email: rudipurwono@feb.unair.ac.id

2Department of Economics, Universitas Airlangga, Indonesia.

Email: jopie.tamtelahitu-2014@feb.unair.ac.id

${ }^{3}$ Department of Economics, Universitas Airlangga, Indonesia.

Email: mkmubin@feb.unair.ac.id

(c) Copyright: The Author(s)

This is an Open Access article distributed under the terms of the Creative Commons Attribution Non-Commercial License (https://creativecommons.org/licenses/by-nc/4.0/) which permits unrestricted non-commercial use, distribution, and reproduction in any medium, provided the original work is properly cited. one of which is the Non-Performing Loan (NPL) indicator. The ratio of bad loans (NPL) is very important, not only for banks but also for the country's economy. The existence of a banking crisis that can cause a country's economic crisis can be detected from the development of bank NPLs in that country (Castro, 2013; Reinhart \& Rogoff, 2011).

Performance of NPLs (both decreasing and increasing) is influenced by many external factors beyond the ability of the bank itself. NPL is also influenced by the macroeconomic development of a country such as GDP growth, exchange rates, and loan interest rates (Beck et al. 2013). Zaidi et al. (2013) in their research states that there is an influence of macroeconomic variables abroad (US and Japan) and also macroeconomic variables in the country on the NPL. The world economy is currently running within the framework of globalization, everything goes beyond the border. A country's economy is interrelated with the economy of another country If there is one economic variable changes in a country, it will have an impact also in other countries' economies, which can therefore, affect the world economy as a whole. Trade and capital flows are the transmissions that can change a country's economy due to the policies in other countries. 
In 2015, Rupiah weakened sharply to Rp 13,850 per US dollar. This value is considered to have exceeded the psychological limit of the Rupiah's exchange rate, which should have been the highest value of only Rp. 13,500 per US dollar. Pressure on the Rupiah against the US Dollar is influenced by many things such as Indonesia's trade policy, the Fed's policy of raising the Fed Fund Rate in the US, and economic policies taken by big economy countries such as China, Japan and the European Union.

The weakening of the Rupiah had an impact on the performance of the banking industry at that time. The banking sector performance report in the second quarter of 2015 showed an increase in the ratio of bad loans or NPL. The weakening condition of the rupiah was exacerbated by the high interest rates and high inflation, causing one of them to increase the NPL at that time (Chavez, 2020).

This study aims to analyze the effect of exchange rates and interest rates on the 4 developed countries (US, EU, Japan and China) on the ratio of bad credit in ASEAN-3 (Indonesia, Malaysia, and Thailand). The effect of changes in exchange rates and interest rates in developed countries is transmitted on domestic macroeconomic variables, which in turn affect the level of bank NPLs in ASEAN-3. This study contributes to the existing literature in two aspects. First this study covers 3 countries in ASEAN (Indonesia, Malaysia, and Thailand) so we can compare different responses from each country. Second, because of the interconnectedness of the world economy, it is important to analyze the extent of the linkages of economic activities with the 4 developed countries which are the engine of the world economy, namely the US, European Union (EU), Japan and China on banking activities in ASEAN countries. Currently, the world economy is becoming increasingly dynamic, where the exchange rate is one of the instruments that become the advantage in trading. By using the Structural VAR model, analysis can be done by looking at the short-term and long-term results.

\section{Literature Review}

There are several studies on the relationship between macroeconomic variables, namely, interest rates and changes in exchange rates, to that of the health of banks in terms of the ratio of bad loans. Taiwo and Adesola (2013) in their research on banks in Nigeria found that exchange rate fluctuations can affect the ability of the public to establish or increase the ratio of bad credit. Vogiazas and Nikolaidou (2011) found that macroeconomic variables namely construction and investment expenditure, inflation, unemployment, and foreign debt are related to the development of GDP and the money supply (M2) influences credit risk in Romanian banks. In addition, his research also found that the crisis experienced by neighboring Romania, especially Greece, also affected increasing credit risk in Romania.
Louzis et al. (2012) conducted a study using the dynamic panel data method to determine the determinants of NPL in the Greek banking sector. The results of the study show that for all control variables in the form of macroeconomic variables namely GDP growth, unemployment rates, interest rates, public debt affect the NPL ratio for all loan categories. In addition, the bank's quality management variable also influences the Greek banking NPL ratio.

Research on the relationship between the development of macroeconomic variables and NPL ratios was also conducted in Malaysia (Alizadeh Janvisloo et al., 2013; Lee \& Wang, 2018). In Malaysia, demand and supply shocks have negatively affected NPLs while changes in monetary policy instruments have a positive effect on NPLs (Alizadeh Janvisloo et al., 2013). Rachman et al. (2018) studied the effect of bank-specific factors on NPLs in developing countries. The results show that Indonesian Bank's profitability and credit growth negatively influenced the number of NPLs.

Becketal.(2013) used panel data to examine the determinants of bad loans in 75 countries. Real GDP, exchange rates, and loan interest rates are variables that significantly affect NPLs. For the exchange rate variable, the direction of the impact depends on whether foreign currency loans in the country have a hedging scheme or not, as well as several other matters relating to the regulation of the use of currency systems in the country. Skarica (2014) analyzes the determinants of increasing NPL ratios in European countries. The results show that the NPL increase was significantly caused by slowing economic growth in the region, as well as high unemployment and inflation. Nkusu (2011) also examined the macroeconomic development in relation to NPLs in developing countries. The results also show the same thing that the performance of macroeconomic variables is a determinant of the banking NPL ratio in the country. The research also concluded that the friction found in the credit market caused the country in macroeconomic research to be vulnerable. An increase in NPL in the long run, can hamper economic growth. Banna et al. (2017) examined the effect of the global financial crisis on the efficiency of Bangladesh commercial banks. The study revealed that the crisis period in conjunction with real interest rate has significantly affected the efficiency of commercial banks in Bangladesh.

\section{Methodology}

This study uses secondary data obtained from various sources. Data was obtained from each of the websites of the central banks of the countries that were the subjects of the study (Bank Indonesia, Bank Negara Malaysia, and Bank of Thailand). And also using data from US Forex (www.usforex.com), the Fed (https://fred.stlouisfed.org), and Quandl (www.quandl.com). The observation period starts from 2003 to 2014 each month. Therefore, the total number of observations in this study is 144 observations. The following variables used in this study (see Table 1). 
Table 1. Variables used in this study

\begin{tabular}{|l|l|}
\hline Variable & \multicolumn{1}{c|}{ Description } \\
\hline Exchange Rate & $\begin{array}{l}\text { Exchange rate of domestic currency (IDR; MYR; THB) against one unit of foreign currency } \\
\text { (USD; CHY; JPY; EUR). There will be 12 combinations of exchange rate used in this } \\
\text { observation. }\end{array}$ \\
\hline Foreign interest rates & $\begin{array}{l}\text { Official interest rates set by central banks major economies used in this observation (US } \\
\text { Fed Funds Rate; Japan official interest rate; China official interest rate; and EU official } \\
\text { interest rate) }\end{array}$ \\
\hline Domestic interest rates & Interbank interest rates in Indonesia; Malaysia; and Thailand. \\
\hline Money supply & Sum of money supply or M2 respectively in Indonesia; Malaysia; and Thailand \\
\hline NPL & $\begin{array}{l}\text { Ratio of non-performing loans to total loans of banks in each country, Indonesia; Malaysia; } \\
\text { and Thailand }\end{array}$ \\
\hline
\end{tabular}

This research uses a structural VAR mode to be able to do the analysis. Changes in interest rates in a country is related to the country's efforts to maintain economic balance through its monetary policy in the country. The simultaneous equations of the model can be written as equation (1) below.

$$
\begin{aligned}
& l e_{t}^{i j}=a_{10}+\sum_{n=1}^{p} a_{11} \cdot l e_{t-n}^{i j}+\sum_{n=1}^{p} a_{12} \cdot r_{t-n}^{j}+\sum_{n=1}^{p} a_{13} \cdot \operatorname{lm}_{t-n}^{i} \\
& +\sum_{n=1}^{p} a_{14} \cdot r_{t-n}^{i}+\sum_{n=1}^{p} a_{15} . n p l_{t-n}^{i}+e_{1, t} \\
& r_{t}^{j}=a_{20}+a_{21} \cdot l e_{t}^{i j}+\sum_{n=1}^{p} a_{22} \cdot l e_{t-n}^{i j}+\sum_{n=1}^{p} a_{23} \cdot r_{t-n}^{j}+\sum_{n=1}^{p} a_{24} \cdot l m_{t-n}^{i} \\
& +\sum_{n=1}^{p} a_{25} \cdot r_{t-n}^{i}+\sum_{n=1}^{p} a_{26} . n p l_{t-n}^{i}+e_{2, t} \\
& l m_{t}^{i}=a_{30}+a_{31} \cdot l e_{t}^{i j}+a_{32} \cdot r_{t}^{j}+\sum_{n=1}^{p} a_{33} \cdot l e_{t-n}^{i j}+\sum_{n=1}^{p} a_{34} \cdot r_{t-n}^{j} \\
& +\sum_{n=1}^{p} a_{35} \cdot \operatorname{lm}_{t-n}^{i}+\sum_{n=1}^{p} a_{36} \cdot r_{t-n}^{i}+\sum_{n=1}^{p} a_{37} \cdot n p l_{t-n}^{i}+e_{3, t} \\
& r_{t}^{i}=a_{40}+a_{41} \cdot l e_{t}^{i j}+a_{42} \cdot r_{t}^{j}+a_{43} \cdot l m_{t}^{i}+\sum_{n=1}^{p} a_{44} \cdot l e_{t-n}^{i j} \\
& +\sum_{n=1}^{p} a_{45} \cdot r_{t-n}^{j}+\sum_{n=1}^{p} a_{46} \cdot \operatorname{lm}_{t-n}^{i}+\sum_{n=1}^{p} a_{47} \cdot r_{t-n}^{i} \\
& +\sum_{n=1}^{p} a_{48} . n p l_{t-n}^{i}+e_{4, t} \\
& n p l_{t}^{i}=a_{50}+a_{51} \cdot \operatorname{lm}_{t}^{i}+a_{52} \cdot r_{t}^{i}+\sum_{n=1}^{p} a_{53} \cdot l e_{t-n}^{i j}+\sum_{n=1}^{p} a_{54} \cdot r_{t-n}^{j} \\
& +\sum_{n=1}^{p} a_{55} \cdot \operatorname{lm}_{t-n}^{i}+\sum_{n=1}^{p} a_{56} \cdot r_{t-n}^{i}+\sum_{n=1}^{p} a_{57} . n p l_{t-n}^{i}+e_{5, t}
\end{aligned}
$$

Equation (1) describes the Structural VAR model used for this study. The equation (1) above is estimated for each country - Indonesia, Malaysia, and Thailand. We measured the responses for each country if they responded to the external shock from the US, China, Japan, and European Union. The external shocks are interest rate and exchange rate. We also measured an impact for internal shock, sum of money supply (M2) and domestic interest rate. Totally, there are 12 models in this observation (Table A).

The structural VAR model in this study produces an impulse response function from which the endogenous variable response can be analyzed if exposed to exchange rate shocks, interest rates, money supply (M2) and domestic interest rates. Besides that, from the estimation of structural VAR model, it can also produce variance decomposition (VD) value. VD comparisons can be analyzed to see the short-term and long-term effects of changes in the determinant variables that affect NPL.

Before estimating the model, first we have to examine the stationarity of the data using the ADF test. The stationary test ensures that the data does not have a specific pattern. Second, we have to determine the optimal lag for each model. Determining the optimal lag involves a lot of choices because there are several criteria such as Likelihood Ratio (LR) Final Prediction Error (FPE), Akaike Information Criterion (AIC), Schwarz Information Criterion (SC) and Hannan-Quin Criterion (HQ). We have to decide which one matches the criteria.

Due to the difficulty in choosing the right optimal lag, this study applies 3 stages that are recommended by Ekananda (2014). First, we determine the value of AR roots for each model and it has to be below 1, which means the model is stable (Ender, 2014, p. 287). Second, choose the optimal criteria. Third, if there are multiple options then we have to choose the largest value of adjusted $\mathrm{R}^{2}$ for the variable NPL in the model. 
Matrix from our model in this study has several restrictions which is more than suggested by Cholesky decomposition using formula $\left(n^{2}-n\right) / 2$ (Ender, 2014, p. 315). So, we can say that the model is over-identified. Therefore, it is necessary to examine whether the identification of restrictions can be accepted or rejected by examining the significance of $\chi^{2}$ in the model. If $\chi^{2}$ is significant, then the identifications of restriction can be rejected or in this case, the over-identification can be rejected. Conversely, if $\chi^{2}$ is not significant then the over-identification cannot be rejected.

\section{Data Analysis}

Stationarity test in this study is done using Augmented Dickey-Fuller test, where the test indicating that all 25

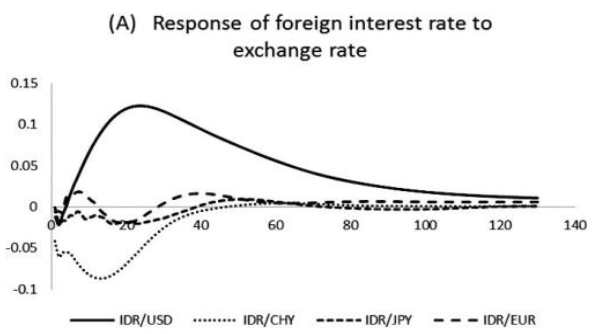

(C) Response of money supply to foreign interest rate

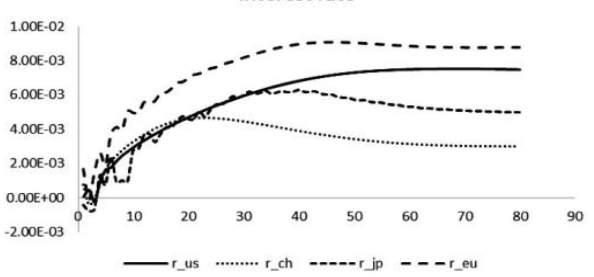

(E) Response of domestic interest rate to foreign interest rate

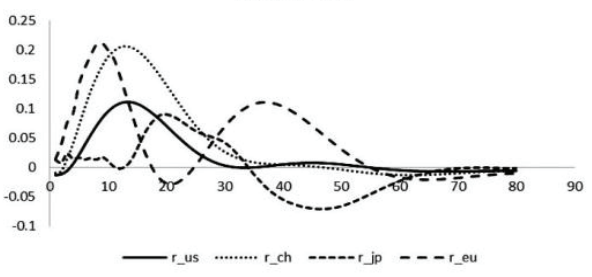

(G) Response of npl to money supply

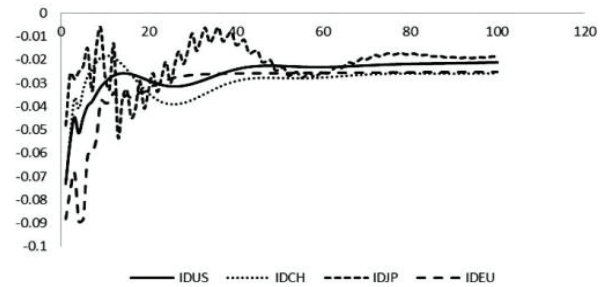

variables has no unit root in $1^{\text {st }}$ difference. Thus, all data is considered valid to use for the estimation. Based on the Cholesky decomposition, the $\chi^{2}$ of all models is not significant. The result concluded that over-identified restrictions on all models cannot be rejected.

\subsection{Impulse Response Function (IRF)}

Figure A.1,A.2, and A.3 summarize the results of impulse response function of Indonesia, Malaysia, and Thailand, respectively.

\subsubsection{IRF for Indonesia}

As shown in Figure A.1 (a) exchange rate shock in period 1 is responded negatively by foreign interest rate.

(B) Response of money supply to exchange rate

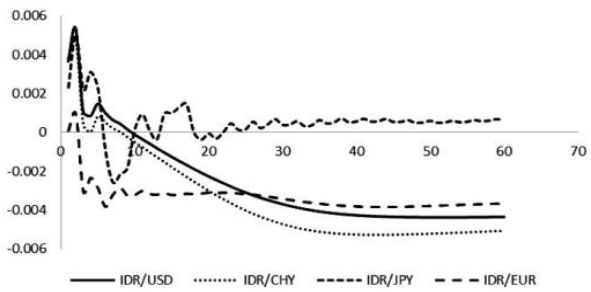

(D) Response of domestic interest rate to exchange rate

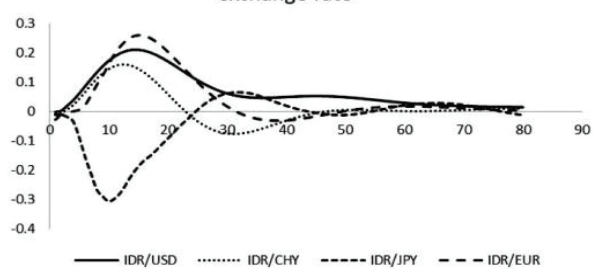

(F) Response of domestic interest rate to money supply

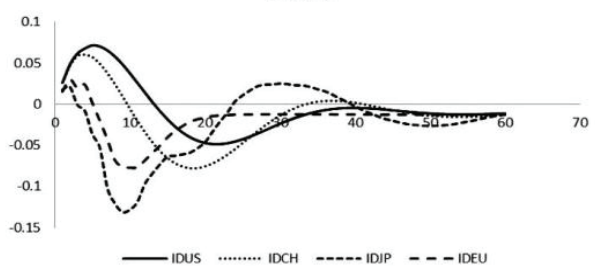

(H) Response of npl to domestic interest rate

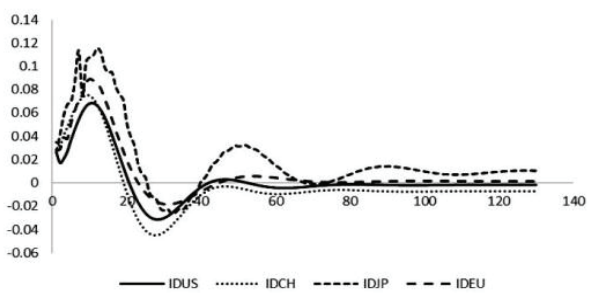

Figure A.1: Impulse Response of Indonesia 
This is consistent theoretically that if Rupiah has appreciated, the foreign interest rate will increase and reach a new equilibrium exchange rate. China's interest rate response rate is the highest $(-0,04152)$ followed by the US $(-0,01203)$, European Union (-0.006083), and Japan (-0.000458). Response of interest rate began to reach convergence after period 50. While the US interest rate requires longer time to reach convergence, that is, in the period 100. Although the Chinese interest rate has higher response than the US, the response of US interest rates last longer than Chinese interest rate response.

Indonesia's interest rate has responded positively to the exchange rate shock (Rupiah relatively to other currency, IDR/USD, IDR/CHY and IDR/EUR) as shown in Figure A.1 (D. This is theoretically consistent. When Rupiah depreciated relatively to the foreign currency (USD, CHY, EUR, and JPY) then Indonesia's domestic interest rate increased to set a new equilibrium exchange rate. From the estimation, Indonesia's domestic interest rate has responded negatively to exchange rate shock of IDR/JPY (Rupiah relative to Japan Yen) until period 25.

Figure A.1 (B) shows Indonesia's money supply (M2) has positively responded to the exchange rate shock. In period 1 , the highest response was caused by IDR/CHY (China) shock (0.003827) and IDR/USD (US) shock (0.003656). The interesting point is the exchange rate shock of IDR/ USD (US) and IDR/CHY (China) are responded by variable money supply (M2) with the same pattern movement. That means changes in the exchange rate of the rupiah against the US dollar and the China Yuan have almost identical responses to money supply, although Yen China has a slightly smaller response.

Indonesia's money supply (M2) has weakly and positively responded to the foreign interest rate shock as shown on Figure A.1 (C). In period 1, the highest response is caused by European Union interest rate shock (0.001673) and the lowest by Japan interest rate shock (-0.00044). The convergence occurs in period 40. Indonesia's government responds to increasing foreign interest rate by increasing money supply to maintain monetary equilibrium.

Figure A.1 (E show the response of Indonesia's interest rate due to foreign interest rate shock. It can be seen that Indonesia's interest rate has positively responded to the foreign interest rate shock. In period 1, the highest response is caused by interest rate shock from European Union (0.014592). The response due to US and China interest rate converges in period 40 . While the response due to the European Union and Japan interest rate converges in period 60.

Figure A.1 (F) shows the response of Indonesia interest rates due to Indonesia's money supply shock. It is shown that Indonesia's domestic interest rate (interbank interest rate) has positively responded to the money supply shock. In period 1, the highest response is caused by the shock of money supply from model IDUS (Indonesia relative to US, 0.026391) and IDCH (Indonesia relatively to China, 0.025931). This may be due to stronger response upon the exchange rate shock IDR/USD and IDR/USD when compared to other exchange rates as shown in Figure A.1 (B).

Indonesia's NPL response to Indonesia money supply and interest rates can be seen in Figure A.1 (G) and Figure A.1 (H). Indonesia's NPL has negatively responded to the money supply shock. This means if Indonesia's money supply increases, it will be responded to by the decline in NPL. The reason to add money supply in the market is to increase public demand which in turn will boost demand for loans. The rising demand for loans, followed by the client's ability to repay the loan plus interest, then will lower the NPL ratio. The highest response is caused by the shock of Indonesia's money supply in the IDEU (Indonesia relative to EU) model. This means the transmission of the external factors from European Union has the greatest impact on the Indonesia NPL through money supply shock. The smallest transmission of external factors resulting from the estimation is from Japan. The convergence took place in period 40.

Indonesia's NPL has positively responded to the interest rate. Logically, if the interest rate increases, it will increase the burden of the borrower to repay the loan and its interest. Furthermore, this will increase the risk of bad loans or in other words it means increasing NPL. It can be seen that the transmission of external factors from the four large economies (US, China, EU, and Japan) to NPL in Indonesia through domestic interest rates has almost the same direction and magnitude. Similar to the response of NPL to money supply, the convergence occurs in period 40 .

\subsubsection{IRF for Malaysia}

Figure A.2 (A) shows that the exchange rate shock MYR/ CHY and MYR/JPY are negatively affected by Chinese and Japanese interest rates. Whereas, the exchange rate shock MYR/USD and MYR/EUR positively responded to US and EU interest rates. This positive relationship indicates that if the US Dollar and Euro depreciates against the Malaysian Ringgit, the United States and the European Union would react by lowering their interest rates or at least it can be said that US interest rates and the European Union do not react to changes in exchange rates MYR/USD and MYR/EUR. The United States and European Union are the two countries that largely invest in Malaysia. Therefore, interest rates in the United States and the European Union do not respond to changes in their exchange rate so that their investments in Malaysia are not affected. In addition, US-Malaysian relations in the Trans-Pacific Partnership since 2010 also have an influence. The response to the shock of foreign 
exchange rate convergence in period 60 except for MYR/ USD in period 120 . The time required for convergence is longer than the model for Indonesia. While in Figure A.2 (D), Malaysia's interest rate has negatively responded to the exchange rate shock. The direction of Malaysia's exchange rates and interest rates is theoretically consistent, where the exchange rate changes will be responded to by adjusting interest rates in Malaysia to obtain a new equilibrium. The convergence of domestic interest rates response to the exchange rate shock occurs in period 130. Compared with the model for Indonesia, the timing of convergence in the model for Malaysia is longer.

(A) Response of foreign interest rate to exchange rate for Malaysia

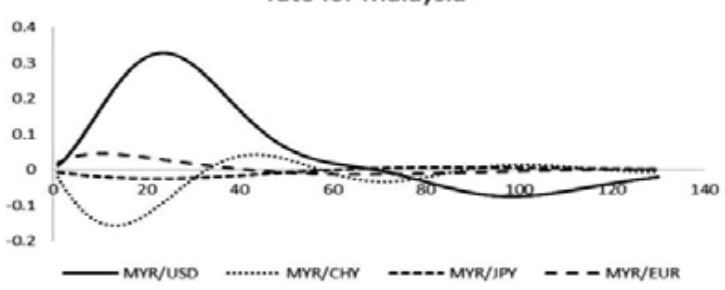

(C) Response money supply to foreign interest rate for Malaysia

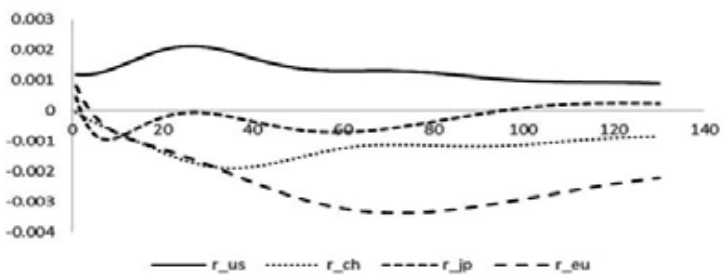

(E) Response of domestic interest rate to foreign interest rate for Malaysia

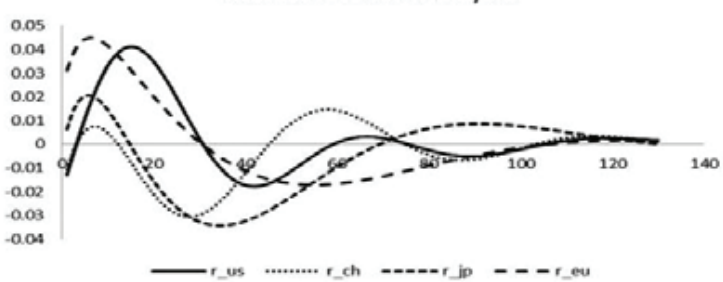

(G) Response of NPL to money supply for Malaysia

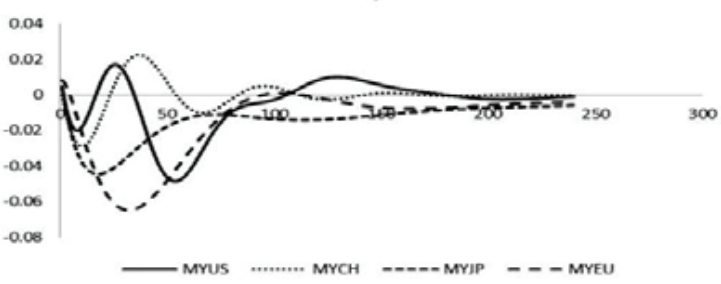

Figure A.2 (B) shows that Malaysia's money supply response to the exchange rate shock. It shows that Malaysia's money supply has negatively responded to the exchange rate shocks MYR/USD and MYR/CHY. Whereas, Malaysia's money supply has positively responded to the exchange rate shocks MYR/JPY and MYR/EUR. In period 1, the greatest response is MYR/USD (-0.000913). The weakest response is caused by the shock of the exchange rate MYR/JPY, but in the next period the response is greater. The most rapid convergence is by the MYR/USD and MYR/EUR shocks in period 50. While the longest convergence is by the MYR/ JPY shock.

(B) Response of money supply to exchange rate for Malaysia

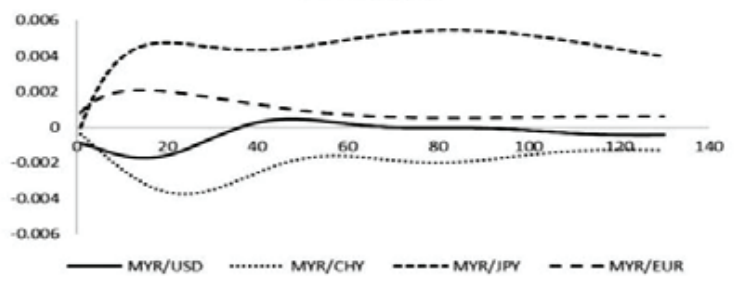

(D) Response of domestic interest rate to exchange rate for Malaysia

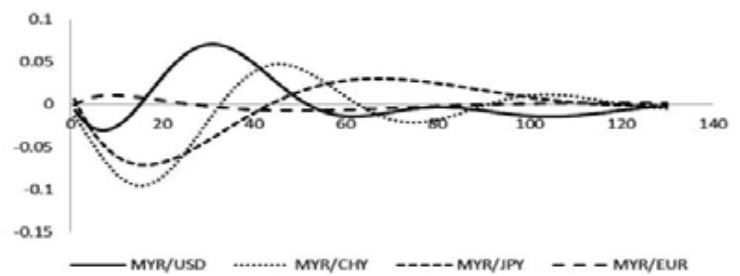

(F) Response of domestic interest rate to money supply for Malaysia

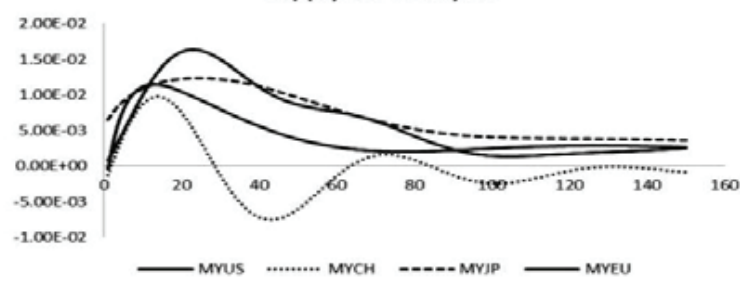

(H) Response of NPL to domestic interest rate for Malaysia

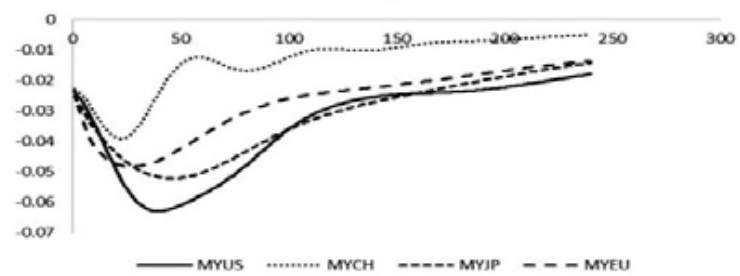

Figure A.2: Impulse Response of Malaysia 
In Figure A.2 (C), Malaysia's money supply has positively responded to the interest rate shock from America, Japan, and the European Union. The Malaysian government has responded to the increasing interest rates in the United States, Japan, and the European Union by raising the interest rates through money supply. Malaysia's money supply has negatively responded to the interest rate shock from China, which means changes in China's interest rates had a small impact on Malaysia's money supply.

Figure A.2 (E) shows the response of Malaysia's domestic interest rates to the foreign interest rate shocks. Malaysia's interest rate has positively responded to the foreign interest rate shock. That means when the United States, China, Japan and European Union change their interest rates, Malaysia will change its interest rate in the same direction. Convergence is achieved in period 120, which means longer than the model for Indonesia.

Figure A.2 (F) shows Malaysia's interest rate has positively responded to the money supply shock. The relationship between money supply and interest rates is in line with the theory. The highest response in the first period occurred in the model MYJP (Malaysia relative to Japan) that is equal to 0.006489 , and the lowest is by the MYUS (Malaysia relative to US) model. Convergence is achieved in period 100 except for the MYCH (Malaysia relatively to China) model in period 130. The convergence time is much longer than the model for Indonesia.

The response of Malaysia NPL caused by the Malaysia money supply and interest rate shocks can be seen in Figure A.2 (G) and A.2 (H). Malaysia's NPL has negatively responded to the interest rate shock. The direction of interest rates relation to NPL is not theoretically consistent, so it is questionable. Malaysia's NPL has negatively responded to the money supply shock; however, the negative response occurs after period 1, specifically, in the models of MYUS, MYJP, and MYEU. The response of NPL due to money supply shock requires 200 periods to achieve convergence. While the response of NPL due to interest rate shock takes more than 200 periods to achieve convergence.

\subsubsection{IRF for Thailand}

In Figure A.3 (a), the exchange rate shock THB/ USD (before the period 2), THB/CHY, and THB/JPY are negatively responded by interest rates from the United States, China, and Japan. Nevertheless, the exchange rate shock THB/JPY is weakly responded by Japan's interest rate with convergence occurs in a shorter period, in the period 50. While the exchange rate shock THB/EUR is positively responded by the European Union's interest rate. The weakest response is caused by the THB/JPY shock. While the most powerful response is caused by the THB/USD shock, the convergence occurs in the period 80 , same as the shock THB/JPY.

Figure A.3 (B) shows Thailand's money supply has negatively responded to the exchange rate shock, except for THB/JPY. The strongest response rate shock is THB/ USD and THB/JPY. While the weakest response is the THB/ CHY shock. In general, the convergence is faster than the model for Malaysia, but longer than the model for Indonesia. Thailand's money supply response against foreign interest rate shock in Figure A.3 (C) shows that Thailand's money supply has weakly responded to the interest rate shock (from the United States, China, and the European Union). Whereas Thailand's money supply has a stronger response to the shock of Japan's interest rates.

Thailand's interest rate response to the exchange rate shock can be seen in Figure A.3 (D). It shows that Thailand's interest rate has positively responded to the exchange rate shock of THB/USD, THB/CHY and THB/EUR (for the period after period 3). Whereas, Thailand's interest rate has negatively responded to the THB/JPY shock, which remains a mystery. The strongest interest rate response is caused by THB/USD shock. The convergence occurs in period 70 .

Figure A.3 (E) shows that Thailand's interest rate has positively responded to foreign interest rate shock. The strongest response is shown by the shock of US interest rates. The convergence occurs in period 50. Thailand's interest rate has responded negatively to the money supply shock as seen in Figure A.3 (F). The strongest response is caused by the shock of the money supply in the model THJP (Thailand relatively to Japan). The convergence occurs in period 40.

In Figure A.3 (G) and A.3 (H), NPL has negatively responded to the shock of Thailand's money supply and interest rates. A negative relationship between the interest rate and the NPL is shown in Figure A.3 $(\mathrm{H})$ is questionable. NPL response caused by the shock of money supply in all models have similar magnitude and converge in period 100.

\section{Discussion and Recommendation}

Although the Fed interest rate is often taken as the reference for many countries in setting their domestic policy, this study shows that the Fed Funds Rate (US official interest rate) is not always the dominant factor in determining domestic policies of many countries including NPL in ASEAN-3 (Indonesia, Malaysia, and Thailand). In general, it was found that in the short run, NPL in Indonesia, Malaysia and Thailand is determined by domestic factors, especially their money supply. While in the long run, the NPL is more determined by external factors, namely the exchange rate and foreign interest rate, except for Thailand. NPL in Indonesia is very vulnerable to external factors, especially, from the 


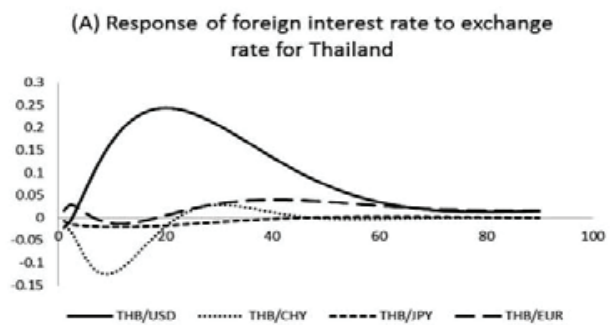

(C) Response of money supply to foreign interest rate for Thailand

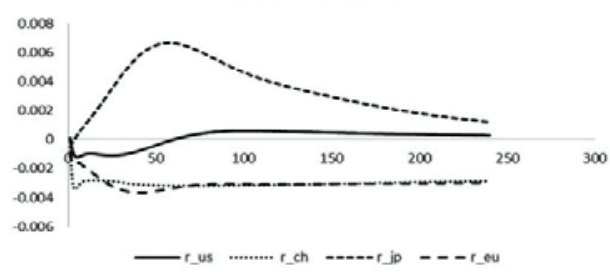

(E) Response of domestic interest rate to foreign interest rate for Thailand

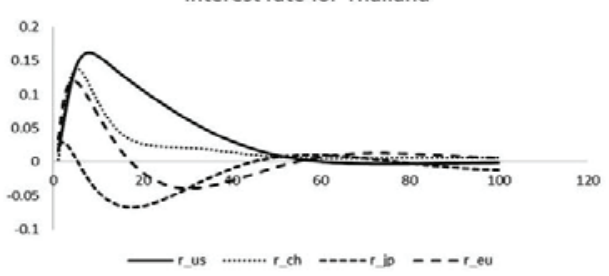

(G) Response of NPL to money supply for Thailand

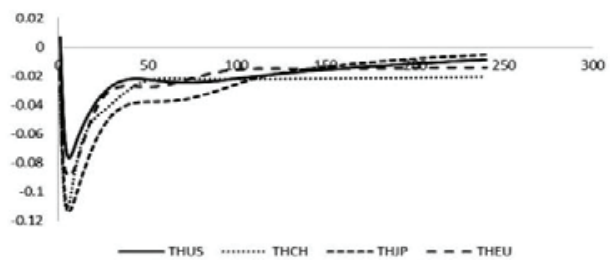

(B) Response of money supply to exchange rate for Thailand

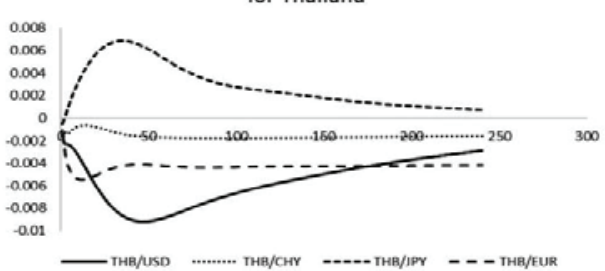

(D) Response of domestic interest rate to exchange rate for Thailand

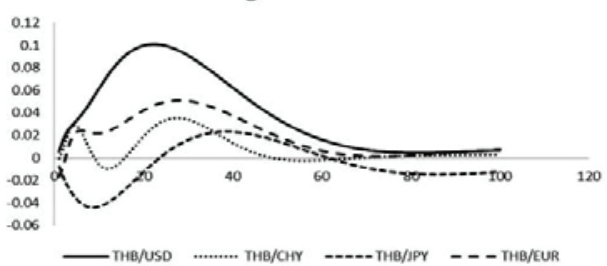

(F) Response of domestic interest rate to money supply for Thailand

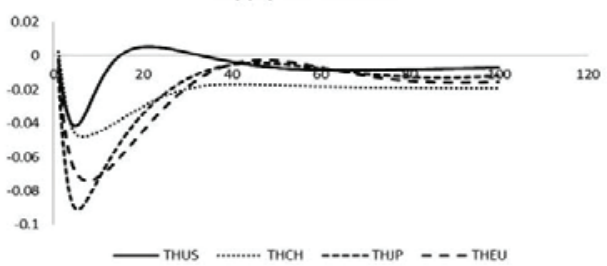

(H) Response of NPL to domestic interest rate for Thailand

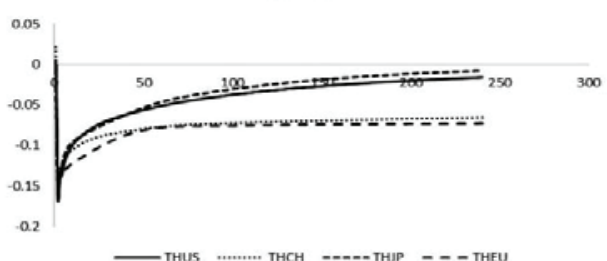

Figure A.3: Impulse Response of Thailand

European Union, namely interest rate. Nevertheless, NPL in Malaysia is more vulnerable to external factors from China. In contrast, Thailand NPL is very susceptible to changes in domestic factors, while the only external factor that influences is the exchange rate against the US dollar. These empirical results state that in the long term, domestic policy, especially monetary policy is strongly influenced by external factors, as stated also by Baharumshah et al. (2013) and Zaidi and Fisher (2010). The relative sizes of various external factors affecting the NPL ASEAN-3 show that Malaysia is the country's most vulnerable, followed by Indonesia and then Thailand.

\section{References}

Agnello, L., \& Sousa, R. M. (2012). How do banking crises impact on income inequality? Applied Economics Letters, 19(15), 1425-1429. https://doi.org/10.1080/13504851.2011.631885.

Alizadeh Janvisloo, M., Muhammad, J., \& Hassan, T. (2013). Macroeconomics shocks and stability in Malaysian banking system; A structural VAR model. American Journal of Economics, 3(C), 22-28. http://dx.doi:10.5923/c. economics.201301.05

Baharumshah, A. Z., Soon, S. V., \& Hamzah, N. A. (2013). Parity reversion in real interest rate in the Asian countries: Further 
evidence based on local-persistent model. Economic Modelling, 35, 634-642. http://dx.doi.org/10.1016/j.econmod.2013.08.024

Banna, H., Rubi, A., \& Koh, E. H. Y. (2017). Determinants of commercial banks' efficiency in Bangladesh: Does crisis matter? Journal of Asian Finance, Economics and Business, 4(3), 19-26. http://dx.doi.org/10.13106/jafeb.2017.vol4.no3.19

Beck, R., Jakubik, P., \& Piloiu, A. (2013). Non-performing loans: What matters in addition to the economic cycle? ECB Working Paper No.1515. Frankfurt, Germany: European Central Bank.

Castro, V. (2013). Macroeconomic determinants of the credit risk in the banking system: The case of the GIPSI. Economic Modelling, 31, 672-683. http://dx.doi.org/10.1016/j.econmod.2013.01.027

Chavez, C. (2020). Determinant of real exchange rate: A behavioural and fundamental dynamic analysis in latin American countries. Journal of Developing Economies, 5(1), 70-85. 10.20473/jde. v5i1.18814

Ekananda, M. (2014). Time series data analysis: for research in economics, management, and accountancy (1st ed.). Jakarta, Indonesia: Mitra Wacana Media.

Lee, J. W., \& Wang, Z. (2018). Spillover effects of foreign direct investment inflows and exchange rate on the banking industry in China. Journal of Asian Finance, Economics and Business, 5(2), 15-24. http://doi.org/10.13106/jafeb.2018.vol5.no2.15

Louzis, D. P., Vouldis, A. T., \& Metaxas, V. L. (2012). Macroeconomic and bank-specific determinants of nonperforming loans in Greece: A comparative study of mortgage, business and consumer loan portfolios. Journal of Banking \& Finance, 36(4), 1012-1027. http://dx.doi.org/10.1016/j. jbankfin.2011.10.012

Mishkin, F. S. (2015). The economics of money, banking and financial markets. London, UK: Pearson Education.
Nkusu, M. (2011). Non-performing loans and macro-financial vulnerabilities in advanced economies. IMF Working Papers WP/11/161. Washington, DC: International Monetary Fund. https://www.imf.org/external/pubs/ft/wp/2011/wp11161.pdf

Rachman, R. A., Kadarusman, Y. B., Anggriono, K., \& Setiadi, R. (2018). Bank-specific factors affecting non-performing loans in developing countries: Case study of Indonesia. Journal of Asian Finance, Economics and Business, 5(2), 35-42. https:// doi.org/10.13106/jafeb.2018.vol5.no2.35

Reinhart, C. M., \& Rogoff, K. S. (2011). From financial crash to debt crisis. The American Economic Review, 101(5), 1676-1706.

Skarica, B. (2014). Determinants of non-performing loans in Central and Eastern European countries. Financial Theory and Practice, 38(1), 37-59. http://dx.doi.org/10.3326/fintp.38.1.2

Taiwo, O., \& Adesola, O. A. (2013). Exchange rate volatility and bank performance in Nigeria. Asian Economic and Financial Review, 3(2), 178-185.

Vogiazas, S. D., \& Nikolaidou, E. (2011). Investigating the determinants of nonperforming loans in the Romanian Banking System: An empirical study with reference to the Greek crisis. Economics Research International, 2011. 1-13. https://doi. org/10.1155/2011/214689

Zaidi, M. A. S., \& Fisher, L. A. (2010). Monetary policy and foreign shocks: A SVAR analysis for Malaysia. Korea and the World Economy, 11(3), 527-550.

Zaidi, M. A. S., Karim, Z. A., \& Azman-Saini, W. N. W. (2013). Foreign and domestic shocks: macroeconomic responses of ASEAN-3 countries. Global Economic Review, 42(3), 215237. doi:10.1080/1226508X.2013.835900 